\title{
Caries Experience in Filipino Children with Cleft Lip and/or Palate from the Noordhoff Craniofacial Foundation, Philippines
}

\author{
Cecile Ammeli Tuaño-Cabrera, ${ }^{1,2}$ Eula C. Ildefonso ${ }^{3}$ and Maria Blanca S. Palabrica ${ }^{3}$ \\ ${ }^{1}$ Graduate Program in Orthodontics, \\ College of Dentistry, University of the Philippines Manila \\ ${ }^{2}$ Noordhoff Craniofacial Foundation Philippines \\ ${ }^{3}$ College of Dentistry, University of the Philippines Manila
}

\begin{abstract}
Objective. This study aims to provide an overview and statistical data on the prevalence of dental caries and caries index scores in Filipino children from the Noordhoff Craniofacial Foundation Philippines, Incorporated (NCFPI).

Methods. A retrospective quantitative descriptive study was undertaken based on pretreatment records of 332 children aged 2 to12 years, with cleft lip $(\mathrm{CL})$, cleft palate $(\mathrm{CP})$, or cleft lip and palate (CLP).

Results. The prevalence of caries ranged from $81 \%$ to $100 \%$. There were significant differences in $\mathrm{dmft}$ scores between the 2 to 5 year-olds and the 6 to 9 year-olds $(p<0.0001)$, and between the 6 to 9 year-olds and the 10 to 12 year-olds $(p<0.0001)$. There were also significant differences between the DMFT scores of the 6 to 9 year-olds and the 10 to 12 year-olds $(p<0.0001)$, between the $C L$ and $C P$ groups $(p<0.0001)$, and between the $C L$ and $C L P$ groups $(p<0.0001)$. There were no significant differences in $\mathrm{dmft}$ and DMFT scores between the males and females.
\end{abstract}

Conclusion. There is high caries prevalence in children with $\mathrm{CL}$, CP and CLP. Caries index scores are higher with increasing age. Poor oral hygiene and the presence of other predisposing factors increase their susceptibility to caries.

Key Words: cleft lip and palate, caries, incidence, Philippines

\section{Introduction}

Cleft lip and palate (CLP) is one of the most common congenital craniofacial abnormalities of newborns in the Philippines. ${ }^{1}$ The Philippines has one of the highest rates of oral clefting in the world, affecting approximately 1 out of

Presented at the Poster Exhibit of the International Orthodontic Congress, September 27-30, 2015, ExCel, London, United Kingdom.

Corresponding author: Cecile Tuano Cabrera, DMD, MSD

Graduate Program in Orthodontics

College of Dentistry

University of the Philippines Manila

Pedro Gil St., Ermita, Manila 1000 Philippines

Telephone: +6327753148

Email: capt2002ph@yahoo.com
500 newborns $^{2}$ in the country. In a series of epidemiologic studies done from 1989 to 1996 in six sites within the country, the prevalence of cleft lip and palate was 1.94 per 1000 live births. ${ }^{3}$ An infant/child with oral cleft endures physical disabilities like speech, hearing, and dental problems. ${ }^{4}$ Due to this defect, the child's oral health and function are compromised. Children with CLP have a higher prevalence of dental abnormalities than do children without clefts. Tooth malformations and malpositions, along with problems such as crowding and the presence of fistulas, are among the predisposing factors in the development of dental caries. Due to the presence of these predisposing factors in children with CLP, one can assume for them to have a high caries index. ${ }^{5}$

The prevalence of dental caries in patients with CLP has been researched extensively in different parts of the world. ${ }^{6-11}$ However, there is little published research regarding dental caries prevalence and/or incidence in individuals with CLP in the Philippines. On the other hand, the 2006 National Oral Health Survey conducted among the public school population in the Philippines has shown that 6-year-old schoolchildren have $97 \%$ overall caries prevalence. ${ }^{12}$ The same report disclosed that 12 year-old Filipino children have $82 \%$ overall caries prevalence in both the primary and permanent dentition. These findings show just how much dental caries continues to be a problem even for noncleft Filipino children.

The Noordhooff Craniofacial Foundation Philippines, Inc. (NCFPI) was chosen as the source of the sample population because it provides the most comprehensive, multidisciplinary care (e.g. General Dentistry, Orthodontics, Speech Therapy, Pediatrics, Pediatric Dentistry, Oral and Maxillofacial Surgery, Plastic Surgery, etc.) out of all organizations in the Philippines providing cleft treatment from birth to adulthood.

The study aims to provide an overview and statistical data on the incidence and prevalence of dental caries in Filipino children with CLP. With these, comparative studies on caries incidence between children with CLP and control groups may be done in future studies. These data can also be used by dental health care professionals as a guide in imparting the necessary oral hygiene instructions to the 
parents and caregivers of children with CLP, in order to lessen pre-surgical dental treatment in other cases of CLP in the future. Since a multidisciplinary and holistic approach is being advocated for the treatment of CLP, effective caries prevention measures will be beneficial to organizations and foundations that provide a wide range of treatment procedures.

\section{Methods}

A retrospective quantitative descriptive study was carried out based on pretreatment records of children with CLP from NCFPI. These children were treated by dentists from the Pediatric Dentistry Center Philippines (PDCP) from 2009 to 2012 at NCFPI's craniofacial center. Statistical data on the incidence of dental caries in relation to age, sex, and type of oral cleft were collected and analyzed. NCFPI and PDCP solicited informed consent during the initial consultation. This study was approved by the ethical review board of the University of the Philippines College of Dentistry.

The criteria for the population included male and female Filipino children, aged 2 to 12 years with unilateral or bilateral cleft lip (CL), cleft palate $(\mathrm{CP})$, or cleft lip and palate (CLP) who were treated at Our Lady of Peace Hospital Craniofacial Center (OLPCC), a center operated by the NCFPI. Those with associated congenital malformations or syndromes and contributory systemic diseases were excluded from the study. The data gathered included the patients' age, gender, cleft type, and dmft/ DMFT records. The dmft measures the number of decayed, missing and filled teeth in the primary dentition, while the DMFT is the counterpart measure for the permanent teeth. Both are universally accepted standard measures of caries experience. Higher dmft/DMFT scores indicate more numbers of teeth that are decayed, missing and filled.

Relevant data from the questionnaires incorporated in the patient records were also reviewed to draw information related to the children's oral health status and caries riskassessment. A total of 395 dental records of NCFPI patients passed the criteria and out of this number, a total of 332 contained the complete data. Most of the subjects came from the National Capital Region (NCR) and Region IV-A (CALABARZON). However, there were a few who came from Visayas and Mindanao (0.02\%).

Using purposive sampling, the population was grouped according to age, sex, and cleft type (CL, CP, or CLP). Since NCFPI has treated approximately a total of 2,500 patients as of this writing, records dating from 2009 up to 2012 were utilized to acquire an ample amount of samples. The computed sample size with a confidence level of $95 \%$, was determined to be 334 .

For the caries incidence based on age, the children were grouped based on age range- 2-5 years old (primary dentition), 6-9 years old (early mixed dentition) and 10-12 years old (late mixed dentition). Table 1 shows the distribution of the sample according to sex and age group. Table 2 shows the number of children with primary and permanent teeth by age group while Table 3 shows the number of children with primary and permanent teeth by cleft type.

Table 1. Sample distribution by sex and age group

\begin{tabular}{lcccc}
\hline \multirow{2}{*}{ Age Group (years) } & \multicolumn{2}{c}{ Male } & \multicolumn{2}{c}{ Female } \\
\cline { 2 - 5 } & Frequency & \% & Frequency & \% \\
\hline $\mathbf{2}-\mathbf{5}$ & 113 & 34.03 & 96 & 28.92 \\
$\mathbf{6 - 9}$ & 56 & 16.87 & 41 & 12.35 \\
$\mathbf{1 0}-\mathbf{1 2}$ & 13 & 3.92 & 13 & 3.91 \\
Total & 182 & 54.82 & 150 & 45.18 \\
\hline
\end{tabular}

Table 2. Number of children with primary and permanent teeth, by age group

\begin{tabular}{lcc}
\hline Age group & $\begin{array}{c}\text { Number of children } \\
\text { with primary teeth }\end{array}$ & $\begin{array}{c}\text { Number of children } \\
\text { with permanent teeth }\end{array}$ \\
\hline 2 to 5 & 209 & 14 \\
6 to 9 & 93 & 84 \\
10 to 12 & 16 & 25 \\
\hline
\end{tabular}

Table 3. Number of children with primary teeth and permanent teeth, by cleft type

\begin{tabular}{lcc}
\hline \multicolumn{1}{c}{ Cleft type } & $\begin{array}{c}\text { Number of children } \\
\text { with primary teeth }\end{array}$ & $\begin{array}{c}\text { Number of children } \\
\text { with permanent teeth }\end{array}$ \\
\hline Cleft lip & 58 & 20 \\
Cleft palate & 58 & 22 \\
Cleft lip and palate & 133 & 50 \\
\hline
\end{tabular}

The data were analyzed by using Microsoft Excel 2013 and MedCalc 16.1. The Mann Whitney-U test was used to determine significant differences between the different age groups, the sexes and the different cleft types. The level of significance was set at $\mathrm{p}<0.05$.

\section{Results}

Table 4 shows the average dmft, DMFT, their components and standard deviation by age group. The mean $\mathrm{dmft}$ values were 11.8, 11.98 and 3.4 for the 2 to 5 -year-olds, the 6 to 9 -year-olds and the 10 to 12-year-olds, respectively. The mean DMFT scores were 3.39 and 8.80 for the 6 to 9 year-olds and the 10 to 12-year-olds, respectively.

Table 5 shows the mean and standard deviation of the caries indices by sex. The mean dmft scores for males and females were almost the same -- 11.49 and 11.31, respectively. The mean DMFT values for males and females were 4.10 and 4.19 , respectively.

Table 6 shows the mean caries indices and standard deviation by cleft type. The mean $\mathrm{dmft}$ scores for the cleft lip, cleft palate, and the cleft lip and palate groups were: $10.96,12.43$ and 11.45 , respectively. The mean DMFT scores were $3.35,3.41$ and 4.4 , respectively. 
Table 4. Mean and standard deviation of caries indices in children with oral clefts by age group

\begin{tabular}{lcc}
\hline \multicolumn{1}{c}{ Variable } & 2 to 5 year-olds & 6 to 9 year-olds \\
\hline Prevalence dmft / DMFT & $95.12 \%$ & $100 \% / 83.53 \%$ \\
$\mathrm{dt} \pm \mathrm{SD} / \mathrm{DT} \pm \mathrm{SD}$ & $10.96 \pm 6.02$ & $10.38 \pm 4.49 / 3.03 \pm 2.30$ \\
$\mathrm{mt} \pm \mathrm{SD} / \mathrm{MT} \pm \mathrm{SD}$ & $0.67 \pm 1.43$ & $\mathbf{1 2}$ year-olds \\
$\mathrm{ft} \pm \mathrm{SD} / \mathrm{FT} \pm \mathrm{SD}$ & $0.06 \pm 0.39$ & $1.44 \pm 2.66 / 0.14 \pm 0.54$ \\
$\mathrm{dmft} \pm \mathrm{SD} / \mathrm{DMFT} \pm \mathrm{SD}$ & $11.80 \pm 6.05$ & $0.16 \pm 0.74 / 0.12 \pm 0.66$ \\
\end{tabular}

Table 5. Mean and standard deviation of caries indices in children with oral clefts by sex

\begin{tabular}{lcc}
\hline \multicolumn{1}{c}{ Variable } & Females & Males \\
\hline Prevalence dmft / DMFT & $97.16 \% / 79.66 \%$ & $96.53 \% / 81.82 \%$ \\
$\mathrm{~d} \pm$ SD / DT \pm SD & $10.26 \pm 5.84 / 3.60 \pm 3.64$ & $10.56 \pm 5.5 / 3.59 \pm 3.49$ \\
$\mathrm{mt} \pm$ SD / MT \pm SD & $0.97 \pm 2.13 / 0.33 \pm 0.78$ & $0.81 \pm 1.68 / 0.24 \pm 0.84$ \\
$\mathrm{ft} \pm$ SD / FT \pm SD & $0.08 \pm 0.46 / 0.26 \pm 1.25$ & $0.10 \pm 0.56 / 0.15 \pm 0.73$ \\
$\mathrm{dmft} \pm$ SD / DMFT \pm SD & $11.31 \pm 5.81 / 4.19 \pm 4.04$ & $11.49 \pm 5.50 / 4.10 \pm 3.85$ \\
\hline
\end{tabular}

Table 6. Mean and standard deviation of caries indices in children with oral clefts by cleft type

\begin{tabular}{lccc}
\hline \multicolumn{1}{c}{ Variable } & Cleft lip & Cleft palate & Cleft lip and palate \\
\hline Prevalence dmft / DMFT & $95.83 \% / 80.95 \%$ & $98.28 \% / 72.73 \%$ & $96.99 \% / 80.00 \%$ \\
$\mathrm{~d} \pm$ SD / DT \pm SD & $9.84 \pm 6.03 / 3.15 \pm 3.45$ & $11.60 \pm 5.70 / 3.18 \pm 3.26$ & $10.55 \pm 5.19 / 3.78 \pm 3.17$ \\
$\mathrm{mt} \pm$ SD / MT \pm SD & $1.02 \pm 2.16 / 0.20 \pm 0.52$ & $0.72 \pm 1.87 / 0.23 \pm 0.96$ & $0.81 \pm 1.12 / 0.34 \pm 0.61$ \\
$\mathrm{ft} \pm \mathrm{SD} / \mathrm{FT} \pm \mathrm{SD}$ & $0.10 \pm 0.48 / 0$ & $0.10 \pm 0.44 / 0$ & $0.08 \pm 0.58 / 0$ \\
$\mathrm{dmft} \pm \mathrm{SD} / \mathrm{DMFT} \pm \mathrm{SD}$ & $10.96 \pm 6.15 / 3.35 \pm 3.80$ & $12.43 \pm 5.64 / 3.41 \pm 5.58$ & $11.45 \pm 5.07 / 4.4 \pm 5.07$ \\
\hline
\end{tabular}

Table 7. $\mathrm{P}$ values of mean caries indices between different age groups, sexes and cleft types

\begin{tabular}{lcc}
\hline \multicolumn{1}{c}{ Variables } & $\mathrm{dmft}$ & DMFT \\
\hline Age group & & \\
2 to 5 year-olds vs. 6 to 9-year olds & 0.85 & --- \\
2 to 5 year-olds vs. 10 to 12 year-olds & $<0.0001$ & --- \\
6 to 9 year-olds vs. 10 to 12 year-olds & $<0.0001$ & $<0.0001$ \\
Sex & & \\
Males vs. Females & 0.84 & 0.94 \\
Cleft type & & \\
Cleft lip vs. cleft palate & 0.30 & $<0.0001$ \\
Cleft lip vs. cleft lip and palate & 0.84 & $<0.0001$ \\
Cleft palate vs. cleft lip and palate & 0.29 & 0.33 \\
\hline
\end{tabular}

Table 8. Oral hygiene behavior and risk-assessment

\begin{tabular}{lcc}
\hline Oral hygiene behavior & Yes & No \\
\hline First dental visit & 142 & 27 \\
Experiences difficulty in tooth brushing & 64 & 34 \\
Has received fluoride in any form & 62 & 50 \\
\hline Habits & Incidence \\
\hline Night time bottle feeding & \multicolumn{2}{c}{79} \\
Thumb sucking & \multicolumn{2}{c}{14} \\
Tongue thrusting & \multicolumn{2}{c}{6} \\
Teeth grinding & \multicolumn{2}{c}{10} \\
Nail biting & \multicolumn{2}{c}{7} \\
Mouth breathing & \multicolumn{2}{c}{7} \\
\hline
\end{tabular}

Table 7 shows the $p$ values comparing the mean $\mathrm{dmft}$ and DMFT scores among the different age groups, sexes and cleft types. There were significant differences in $\mathrm{dmft}$ scores between the 2 to 5 -year-olds and the 6 to 9 -year-olds $(\mathrm{p}<0.0001)$, and between the 6 to 9 -year-olds and the 10 to 12 -year-olds $(\mathrm{p}<0.0001)$. There were also significant differences between the DMFT scores of the 6 to 9 year-olds and the 10 to 12 -year-olds ( $<<0.0001)$, between the $C L$ and $\mathrm{CP}$ groups $(\mathrm{p}<0.0001)$, and between the CL and CLP groups $(\mathrm{p}<0.0001)$.
The questionnaire incorporated in the patient records included questions regarding the patient's oral hygiene and assessment of caries risk. A total of 169 dental records with answered questionnaires (51\%) were reviewed. Table 8 shows the tally of the recorded answers. Most guardians noted that their child brushes his/her teeth just once daily or sometimes do not brush at all. Only $9.47 \%$ of the questionnaire respondents claimed that their children brush their teeth 2-3 times a day. Sixty-two (36.9\%) responded yes when asked if their child has received fluoride; most of them mentioned fluoride in the form of toothpaste.

A checklist of oral habits was included in the oral health risk assessment sheet. Among them, night time bottle feeding was the most common with $46.74 \%$, followed by thumb sucking and teeth grinding with $8.28 \%$ and $5.92 \%$, respectively. The frequency of snacking also showed that the subjects snacked frequently (about 3 times daily), and that their diet included bread, milk, soft drinks, chips, juice, and chocolates, among others. Dental charts also revealed that most of the subjects were diagnosed with mild gingivitis upon the first visit.

\section{Discussion}

There is little information about the incidence and prevalence of caries in individuals with CLP in the Philippines. A study by Jindal et $\mathrm{al}^{13}$ reported that the DMFT in individuals aged 0 to $>45$ years old with clefts in the Philippines ( $\mathrm{n}=103)$, was 11.7. The higher DMFT in Jindal's study compared to the present study may be due to the wider range of ages of the subjects and the location from which the subjects were recruited (Cebu) in the former study.

The results of the present study are similar to the findings of Al-Wahadni et al, ${ }^{9}$ Chapple and Nunn, ${ }^{10}$ and Xiao 
Table 9. Studies of caries prevalence in individuals with cleft lip and palate compared to noncleft individuals

\begin{tabular}{|c|c|c|c|c|c|c|c|}
\hline $\begin{array}{c}\text { Year } \\
\text { published }\end{array}$ & Author & Country & $\begin{array}{c}\text { Age } \\
\text { (years) }\end{array}$ & $\begin{array}{c}\text { Sample } \\
\text { population }\end{array}$ & $\mathrm{dmft}$ & DMFT & $\begin{array}{c}\text { Increased caries } \\
\text { experience compared to } \\
\text { noncleft controls? }\end{array}$ \\
\hline 2013 & $\begin{array}{c}\text { Antonarakis, Palaska } \\
\text { \& Herzog }\end{array}$ & $\begin{array}{l}\text { Meta-analysis } \\
\text { of } 7 \text { studies }\end{array}$ & $1.5-29$ & 474 & $1.51^{*}$ & $1.38^{*}$ & Yes \\
\hline 2013 & King et al. & China & $2-7$ & 132 & $\begin{array}{l}1.5 \text { (2-4 age group) } \\
5.2 \text { (5-7 age group) }\end{array}$ & NA & $\begin{array}{l}\text { Yes (in the 5-7 age } \\
\text { group) }\end{array}$ \\
\hline 2012 & Freitas et al. & Brazil & $12-21$ & 30 & NA & 8.2 & Yes \\
\hline 2012 & Tannure et al. & Brazil & $4-21$ & 115 & 1.68 & 1.2 & No \\
\hline 2011 & Jindal et al. & $\begin{array}{l}\text { Philippines, Guatemala } \\
\text { and Argentina }\end{array}$ & $<6->45$ & 1,593 & $\begin{array}{c}2.47 \text { ( }<6 \text { age group) } \\
5.03 \text { ( } 6 \text { to } 12 \text { age group) }\end{array}$ & 8.13 & No \\
\hline 2010 & Britton \& Wellbury & Scotland & $0.5-6$ & 209 & $1.138^{* *}$ & NA & $\begin{array}{l}\text { Yes (in the } 4.5-6 \text { age } \\
\text { group) }\end{array}$ \\
\hline 2010 & Zhu et al. & China & $3-25$ & 380 & $2.53-2.44$ & $2.56-4.04$ & Yes \\
\hline 2009 & Al-Dajani & Syria & $12-29$ & 106 & NA & 6.83 & Yes \\
\hline 2008 & $\begin{array}{l}\text { Mutarai, Ritthagol and } \\
\text { Hunsrisakhun }\end{array}$ & Thailand & $1.5-3$ & 138 & 9.1 & NA & Yes \\
\hline 2007 & $\begin{array}{c}\text { Stec-Slonicz, Szczepańska } \\
\text { \& Hirschfelder }\end{array}$ & Poland and Germany & $3.5-18$ & 100 & 2.06 & 5.25 & $\begin{array}{l}\text { Yes (compared to } \\
\text { general population) }\end{array}$ \\
\hline 2005 & $\begin{array}{c}\text { Al-Wahadni, Alhaija \& Al- } \\
\text { Omari }\end{array}$ & Jordan & $10-38$ & 32 & NA & $\begin{array}{l}4.76 \text { (10-15 age group) } \\
5.42 \text { (16-38 age group) }\end{array}$ & $\begin{array}{l}\text { Yes (in the } 14-16 \text { age } \\
\text { group compared to } \\
\text { general population) }\end{array}$ \\
\hline 2004 & Besseling \& Dubois & Vietnam & $4-16$ & 154 & 11.20 & $\begin{array}{l}5.06 \text { (11-13 age group) } \\
7.07 \text { (14-16 age group) }\end{array}$ & Yes \\
\hline 2004 & Lages et al. & Brazil & $1-32$ & 78 & $2.77-2.91$ & $1.87-13.62$ & $\begin{array}{l}\text { No (compared to } \\
\text { general population) }\end{array}$ \\
\hline 1989 & Dahllöf & Sweden & $\begin{array}{c}5.5 \\
\text { (mean) }\end{array}$ & 49 & 7.0 & NA & Yes \\
\hline 1964 & Lauterstein \& Mendelsohn & USA & 9 (mean) & 285 & NA & 8.01 & No \\
\hline
\end{tabular}

* mean difference compared to matched noncleft controls

** mean $\mathrm{dmft}$ for all age groups

et al. ${ }^{14}$ The prevalence of caries increased with increasing age. This may be related to the toothbrushing technique and dietary habits. The patients' records showed that tooth brushing of the younger children ( $<6$ years old) is usually performed by their parents or guardians, while those aged 6 to 12 years mostly brush their teeth by themselves. Thoroughness and frequency of brushing may be significantly reduced when the child is not motivated or monitored by their parents. Proper brushing technique may not be practiced by the children. In addition, the level of manual dexterity, especially in young children, may be a significant factor in proper brushing of the teeth. Yiu and Wei ${ }^{15}$ stated that children spend less than 60 seconds brushing their teeth and brush their teeth that are least susceptible to caries. Another factor which may contribute to high susceptibility to dental caries is the intake of sugary food and drink by the children. Older children already attend school and have greater autonomy in choosing what to eat because their diet may not be monitored by their parents.

The results of the present study agree with those of Bian et $\mathrm{al}^{16}$ and Chapple and Nunn, ${ }^{10}$ where there were significant differences in caries experience between those with CL and CP and between those who had CL and CLP. These differences may be attributed to the fact that as a child grows older, there is inadequate access for optimal tooth cleaning in the maxillary anterior area because of the development of crowding and malpositions in those with $\mathrm{CP}$ and CLP. On the other hand, no significant difference in caries incidence among different cleft types were reported by Dahllof et al., ${ }^{5} \mathrm{Al}-$ Wahadni et $\mathrm{al}^{9}$ and Stec-Slonicz et al. ${ }^{8}$ This may be attributed to dissimilarities in age groups, socioeconomic background and dietary habits compared to the present study.

The present findings concur with those of Bian et al, ${ }^{16}$ where there were no significant differences in caries experience between males and females. As of this writing, gender is not a common contributing factor being studied in reports about caries experience in children with clefts.

When compared to other countries, the mean caries indices in the present study were higher compared to studies done in Brazil, ${ }^{17-19}$ China, ${ }^{6,20}$ Jordan, ${ }^{9}$ Poland and Germany, ${ }^{8}$ Sweden, ${ }^{5}$ Syria, ${ }^{21}$ Thailand, ${ }^{22}$ USA $^{23}$ and Vietnam ${ }^{24}$ (Table 9). These differences may be attributed to socioeconomic status, diet or feeding habits in the different studies. On the other hand, caries incidence in these countries may be attributed to factors related to (1) lack of knowledge (fear of brushing the teeth near the cleft, prioritization of medical procedures at the expense of dental treatment and improper tooth brushing technique); (2) socioeconomic circumstances (high cost of professional care, transportation problems and lack of time for dental treatment), and; (3) the defect or anatomy (crowding in the anterior area near the cleft which increases the risk for proximal caries, higher incidence of enamel hypomineralization near the alveolar cleft, and difficulty in tooth cleaning because of crowding and the presence of scar tissue). $5,7,9,16$ 


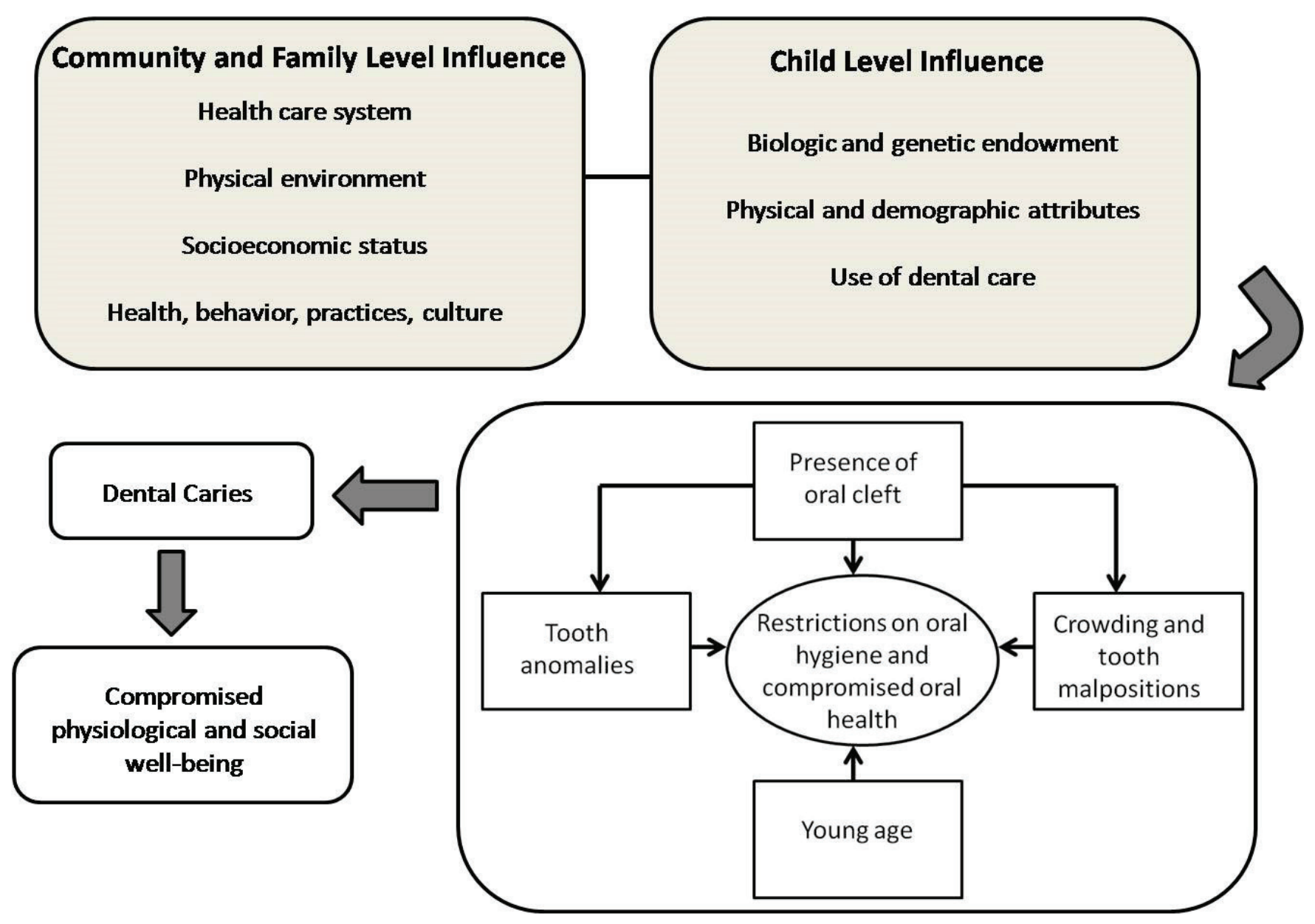

Figure 1. A multi-factorial view on the development of dental caries in children with CLP.

Since the treatment of most of the patients in this study were wholly subsidized by the foundation, it may be assumed that these patients most likely came from low socio-economic families. This means that their dental needs are lower in priority compared to basic needs and medical procedures required in order to treat the cleft. Patients and their parents may be preoccupied with other aspects of their health such as surgery and nutrition that often dental needs are neglected. ${ }^{6}$ Family income and educational level have been shown, in other studies, to affect caries risk, receptivity to instructions from health care professionals, regularity of dental consultations and restriction on the consumption of sweets. ${ }^{25-27}$ These may explain the high caries index scores of these patients in the present study.

Reports that investigated the prevalence of dental caries in cleft individuals, compared to noncleft controls or the general population have been done in other countries and a summary of their findings are shown in Table 9. An overwhelming majority of those studies $5,6,8,9,20-22,28,29$ indicate that there is a higher incidence of caries in individuals with clefts compared to noncleft individuals. The results of the present study indicate that there is high caries experience in children with CL, CP and CLP. The figures in the present study are quite high compared to the World Health Organization and Federacion Dentaire Internationale's millennium goals of a 50\% reduction in caries incidence in 56 year-olds and a DMFT of 3 by the age of $12 .{ }^{30}$

Patients with CLP generally display poorer oral hygiene and higher susceptibility to caries because of the difficulty in achieving adequate plaque control associated with dental anomalies and defects from the lip or palate. ${ }^{31}$ Some of the causes that have been suggested are the irregularity of the teeth 4 and longer oral clearance time. ${ }^{32}$ Besseling ${ }^{24}$ proposed other reasons such as dry mouth caused by mouth breathing habits, less natural cleaning of the teeth because of the morphology and differences in the diet and feeding habits. Parapanisou et al. ${ }^{7}$ suggested that difficulty in tooth cleaning because of the residual scar tissues, lack of interest in oral hygiene due to many other health problems and the fear of brushing in the cleft area.

In a few articles where there was no significant difference in caries experience between patients with CLP and noncleft controls, ${ }^{18}$ the sample population came from a country where universal health care include oral health 
measures for all. ${ }^{33}$ No significant differences were also found in Lauterstein and Mendelsohn's article, ${ }^{23}$ because the control group consisted of the same patients with CLP, but used the teeth on the noncleft side and the lower arch.

The present findings indicate that night time bottle feeding was found to be the leading habit of children with CLP, which is in concurrence with the results of the study done by Mutarai et al. ${ }^{22}$ This habit exposes the teeth to acids produced by cariogenic bacteria, which in turn increases the susceptibility to caries. Another contributing factor is mouth breathing, which causes the mouth to dry and prevents the protective cleansing action of saliva against oral bacteria and the acids that they produce.

Based on NSO's 2000 Census on Disability results and the National Council Disability Affairs, the total number of children in the Philippines aged 1 to 14 with oral defects is 18,128 . However, since there are no specific national data regarding non-syndromic oral clefts in the Philippines for the 2 to 12-year-old age group and because the present study is descriptive by nature, it would be difficult to extrapolate the percentage of subjects included in the present study to the national population. If we extrapolate data using the ratio of 1.94 per 100 live births, ${ }^{3}$ to the number of live births when the subjects were born, the data shown here represents approximately $0.7 \%$ of the total children with oral clefts between 2 and 12 years old.

Based on the present research, the relationship of the different factors which affect caries experience in a child with an oral cleft is presented in Figure 1, based on FisherOwens et al.'s ${ }^{34}$ study. A child's oral health is influenced by factors from the community, family and child level. Dental caries, which may lead to loss of teeth, consequently affects the physiological and social well-being of the child.

There are many ways to decrease the incidence and prevalence of caries. It has been suggested that the first dental visit be done as soon as the child reaches the age of one, or even earlier, than when dental problems are already identified in order to provide preventive measures against caries formation. ${ }^{35}$ Parent-supervised brushing prior to the age of 7 has been advocated as a national guidance in the United Kingdom. ${ }^{36}$ In the Philippines, fluoride, in the form of fluoridated toothpaste is the most effective measure in preventing dental caries. ${ }^{12}$ Modification in the frequency and intake of sugary food may mitigate their effects on caries development. $^{22}$ Training of auxiliary personnel in implementing guidelines in caries prevention and management are also beneficial. ${ }^{37,38}$

The data were gathered from pretreatment records of patients from NCFPI. Unfortunately, the authors were unable to determine if these patients were new patients or former patients who already underwent other procedures at NCFPI. It would be helpful if they can be differentiated so that it can be ascertained if the current preventive programs are effective or not.
Children in this study were not randomly selected because it was not feasible. Another limitation is, since the data relied on existing records, the examiners who performed the charting were not calibrated, thus affecting the reliability of the results. The sample also represented a small segment of the population. However, these findings may shed light on the limited information available regarding CLP in the Philippines. In addition, these may provide baseline information in implementing an effective preventive program in decreasing caries prevalence in children with CLP.

\section{Conclusion and Recommendations}

The incidence and prevalence of caries in children with CL, CP and CLP who sought treatment at the NCFPI are quite high. In addition, there is an increase in caries index scores with increasing age. There are significant differences in caries index scores between $\mathrm{CL}$ and $\mathrm{CP}$ and between $\mathrm{CL}$ and CLP. Poor oral hygiene and the presence of other predisposing factors increase the susceptibility of such a population to the progression of caries. Among these predisposing factors are developmental anomalies and oral habits such as nighttime bottle feeding, thumb sucking and mouth breathing.

Since one of the goals of NCFPI is to provide holistic treatment for CLP patients, an aggressive caries preventive program is necessary to reduce caries prevalence and incidence. In order to lessen the dental treatment procedures for patients with CLP, there is a need to focus on primary intervention. A preventive program which would include dental consultation by the child's first birthday, supervised tooth brushing using fluoridated toothpaste, training of auxiliary personnel in implementing these guidelines and education of the parents/and or guardians regarding the importance and benefits of proper oral hygiene measures, fluoride use, control of oral habits, and diet modification are all beneficial and necessary.

The sample population of the present study consisted only of patients from NCFPI, therefore the authors recommend that another study on a larger scale be carried out so that generalizations may be made to a larger group of those with clefts, from which new wide-ranging policies can be established.

Statement of Authorship

All authors have approved the final version submitted.

Author Disclosure

All the authors declared no conflicts of interest.

Funding Source

None. 


\section{References}

1. Padilla- CD, Cutiongco EM, Sia JM. Birth defects ascertainment in the Philippines. Southeast Asian J Trop Med Public Health. 2003; 34 Suppl 3:239-43.

2. Mossey P, Castilla E. Global Registry and Database on Craniofacial Anomalies. Bauru, Brazil; 2001.

3. Murray JC, Daack-Hirsch S, Buetow $\mathrm{KH}$, et al. Clinical and epidemiologic studies of cleft lip and palate in the Philippines. Cleft Palate Craniofac J. 1997; 34(1):7-10.

4. Wong FW, King NM. The oral health of children with clefts--a review. Cleft Palate Craniofac J. 1998; 35(3):248-54.

5. Dahllöf G, Ussisoo-Joandi R, Ideberg M, Modeer T. Caries, gingivitis and dental abonormalities in preschool children with cleft lip and/ or palate. Cleft Palate J. 1989; 26(3):233-7; discussion 237-8.

6. Zhu WC, Xiao J, Liu Y, Wu J, Li JY. Caries experience in individuals with cleft lip and/or palate in China. Cleft Palate Craniofac J. 2010; 47(1):43-7.

7. Parapanisiou V, Gizani S, Makou M, Papagiannoulis L. Oral health status and behaviour of Greek patients with cleft lip and palate. Eur Arch Paediatr Dent. 2009; 10(2):85-9.

8. Stec-Slonicz M, Szczepańska J, Hirschfelder U. Comparison of caries prevalence in two populations of cleft patients. Cleft Palate Craniofac J. 2007; 44(5):532-7.

9. Al-Wahadni A, Alhaija EA, Al-Omari MA. Oral disease status of a sample of Jordanian people ages 10 to 28 with cleft lip and palate. Cleft Palate Craniofac J. 2005; 42(3):304-8.

10. Chapple JR, Nunn JH. The oral health of children with clefts of the lip, palate, or both. Cleft Palate Craniofac J. 2001; 38(5):525-8.

11. Lucas VS, Gupta R, Ololade O, Gelbier M, Roberts GJ. Dental health indices and caries associated microflora in children with unilateral cleft lip and palate. Cleft Palate Craniofac J. 2000; 37(5):447-52.

12. Monse B, Yanga-Mabunga S. Urgent oral health needs of Filipino children: the results of the 2006 national oral health survey. Developing Dentistry. 2007; 8:7-9

13. Jindal A, McMeans M, Narayanan S, et al. Women are more susceptible to caries but individuals born with clefts are not. Int J Dent. 2011; 2011:454532.

14. Xiao WL, Zhang DZ, Xu YX. The caries prevalence of oral clefts in eastern China. Int J Clin Exp Med. 2015; 8(9):16322-7.

15. Yiu CK, Wei SH. Management of rampant caries in children. Quintessence Int. 1992; 23(3):159-68

16. Bian Z, Du M, Bedi R, Holt R, Jin H, Fan M. Caries experience and oral health behavior in Chinese children with cleft lip and/ or palate. Pediatr Dent. 2001; 23(5):431-4.

17. Freitas ABDA, de Barros LM, Fiorini JE, Boriollo MFG, Moreira AN, Magalhães CS. Caries experience in a sample of adolescents and young adults with cleft lip and palate in Brazil. Cleft Palate Craniofac J. 2012; 50(2):187-91.

18. Tannure PN, Costa MdeC, Küchler EC, Romanos HF, Granjeiro JM, Vieira AR. Caries experience in individuals with cleft lip and palate. Pediatr Dent. 2012; 34(2):127-31.

19. Lages EM, Marcos B, Pordeus IA. Oral health of individuals with cleft lip, cleft palate, or both. Cleft Palate Craniofac J. 2004; 41(1):59-63.

20. King NM, Wong WL, Wong HM. Caries experience of chinese children with cleft lip and palate. Cleft Palate Craniofac J. 2013; 50(4):448-55.
21. Al-Dajani M. Comparison of dental caries prevalence in patients with cleft lip and/or palate and their sibling controls. Cleft Palate Craniofac J. 2009; 46(5):529-31.

22. Mutarai T, Ritthagol W, Hunsrisakhun J. Factors influencing early childhood caries of cleft lip and/or palate children aged 18 to 36 months in southern Thailand. Cleft Palate Craniofac J. 2008; 45(5):468-72.

23. Lauterstein AM, Mendelsohn M. An analysis of the caries experience of 285 cleft palate children. Cleft Palate J. 1964; 29:314-9.

24. Besseling S, Dubois L. The prevalence of caries in children with a cleft lip and / or palate in Southern Vietnam. Cleft Palate Craniofac J. 2004; 41(6):629-32.

25. Bokhout B, Hofman FX, van Limbeek J, Kramer GJ, Prahl-Andersen B. Incidence of dental caries in the primary dentition in children with a cleft lip and/or palate. Caries Res. 1997; 31(1):8-12.

26. Cheng LL, Moor SL, Ho CTC. Predisposing factors to dental caries in children with cleft lip and palate: a review and strategies for early prevention. Cleft Palate Craniofac J. 2007; 44(1):67-72.

27. Pakpour AH, Hidarnia A, Hajizadeh E, Kumar S, Harrison AP. The status of dental caries and related factors in a sample of Iranian adolescents. Med Oral Patol Oral Cir Bucal. 2011; 16(6):e822-7.

28. Antonarakis GS, Palaska PK, Herzog G. Caries prevalence in nonsyndromic patients with cleft lip and/or palate: a meta-analysis. Caries Res. 2013; 47(5):406-13.

29. Kirchberg A, Treide A, Hemprich A. Investigation of caries prevalence in children with cleft lip, alveolus, and palate. J Craniomaxillofac Surg. 2004; 32(4):216-9.

30. Aggeryd T. Goals for oral health in the year 2000: Cooperation between WHO, FDI and the national dental associations. Int Dent J. 1983 33(1):55-9.

31. Cheng L, Moor S, Kravchuk O, Meyers I, Ho C. Bacteria and salivary profile of adolescents with and without cleft lip and/or palate undergoing orthodontic treatment. Aust Dent J. 2007; 52(4):315-21.

32. Ahluwalia M, Brailsford SR, Tarelli E, et al. Dental caries, oral hygiene, and oral clearance in children with craniofacial disorders. J Dent Res. 2004; 83(2):175-9.

33. Pucca GA, Gabriel M, de Araujo ME, de Almeida FCS. Ten years of a national oral health policy in Brazil: innovation, boldness, and numerous challenges. J Dent Res. 2015; 94(10):1333-7.

34. Fisher-Owens SA, Gansky SA, Platt LJ, et al. Influences on children's oral health: a conceptual model. Pediatrics. 2007; 120(3):e510-20.

35. Dental care for a child with cleft lip and palate. Cleft Palate Found [Online]. 2014 [cited 2014 Oct]. Available from www.cleftline.org/parents-individuals/publications/dental-care-for-achild-with-cleft-lip-and-palate/.

36. Gray-Burrows KA, Day PF, Marshman Z, Aliakbari E, Prady SL, McEachan RRC. Using intervention mapping to develop a home-based parental-supervised toothbrushing intervention for young children. Implement Sci. 2016; 11(1):61.

37. Ng MW, Fida Z. Dental Hygienist-Led Chronic Disease Management System to Control Early Childhood Caries. J Evid Based Dent Pract. 2016; 16 Suppl:20-33.

38. Lee GH, McGrath C, Yiu CK. Evaluating the impact of caries prevention and management by caries risk assessment guidelines on clinical practice in a dental teaching hospital. BMC Oral Health. 2016; 16(1):58. 